\title{
A Review on Seismic Behaviour of Zipper Braced Frames
}

\author{
Shubhangi Prakash Shejul*, Rahul Pandit and Wadekar AP \\ Department of Social Sciences, University of Architecture, Civil Engineering and Geodesy, Bulgaria
}

Submission: May 29, 2018; Published: July 02, 2018

*Corresponding author: Shubhangi Prakash Shejul, Department of civil engineering, P.E.S.College of Engineering Aurangabad, Maharashtra, India, Email: shubhangishejul7@gmail.com

\section{Abstract}

For increasing performance of frame structure varioustypes of braces are used in frame structure for seismic design. i.e. X-braced, inverted $\mathrm{V}$ braced, ZX braced, and Zipper braced frame. Inverted-V-braced frames are one type of ordinary concentrically braced frame. The behaviour of this system is controlled by the buckling of the first story braces in compression, resulting in localization of failure and loss of lateral resistance. To overcome this problem of V-bracing and reduce the unbalance force,for improving seismic behavioura vertical structural member added at the beam mid span from the second stories above, called zipper strut. And this new brace called zipper brace. On zipper brace frame more research has been done by researchers in steel by using different software's. This paper represents the review on research conducted on zipper braced frame.

Keywords: Zipper braced frames;Chevron braced frames; Inverted v-braced frames;Time history analysis;Seismic design; CBF; ETABs 2016

\section{Introduction}

The design of earthquake resistant buildings has progressed in recent years. The building has two types frame structure and load bearing structure, in that frame structure is commonly used. Frame structures are the structure which has been made by assembling beam, column and slab at proper position as per requirement to resist the lateral loads and gravity load. Under lateral earthquake loads, simple concrete frames undergo large lateral displacements that may damage structural and non-structural members. Load bearing and frame structures are our traditional structures which we are using sincea years ofconstruction starts for multi storey RCC structures. Most of our building failure studies concluded thatbuildings fail due to formation of diagonal cracks. But using diagonal structural members in frames can increases the capacity of structures against failure. One of the practical ways to prevent these frames undergoing large lateral displacements is to use diagonal members, called brace. A frame in which bracing are used called braced frames. These members increase lateral stiffness of the frame and enhance the capacity of the energy dissipation by plastic deformations. There are various types of braced frame used in steel namely Chevron braced frame, Concentrically Braced Frames (CBF), suspended zipper braced frames, V-brace frame, X- braced frames, XZ- braced frame etc[1]. Adding steel braces enhance greatly the strength capacity of the buildings on the dynamic characteristic of the building the zipper bracing systems are found the most efficient. For seismic analysis of structures various software, methods were applied in field of structural analysis such as time history analysis, response spectra method, push over analysis. Prakriti Chandrakar et al. [2] time history analysis is a more precise in description of the structure under dynamic load and it can give a more precise approximation of the interior stresses and also the time and position of the cracks emerging in the structure.

\section{Previous studies on zipper frame:}

Kadid A et al. [1] investigated the seismic behaviour of RC buildings strengthened with different types of steel braces, X-braced, inverted V braced, ZX braced, and Zipper braced. NaeimeS [3] proposes the behaviour of zipper brace frame by using pushover condition. Chuang-sheng Yang [4] proposes a refined design methodology for zipper braced frames with partialheight zipper mechanisms. Pourbaba $\mathrm{M}$ et al. [5]investigated the behaviour of Zipper Braced Frame (ZBF) and compared with Concentrically Braced Frame. Haifeng Yu et al. [6] proposed that zipper columns are more reasonable design method. Nouri and Imani Kalesar[7]found out that employing suspended zipper braced frame for rehabilitation and strengtheningof existing structure was economical and practical.Rahimi $\mathrm{R}$ et al. [8] proposes through numerical simulations for lateral capacity and seismic behavior zipper braced frames and suspended zipper braced frames.LuciyaTrica et al. [9] studied on to apply suitable static method for zipper column design through nonlinear time 


\section{Civil Engineering Research Journal}

history analysis. And they investigated the inelastic behaviour of zipper braced frame in high rise building in high risk seismic zone (victoriya, BC) under crustal.RazviM [10]proposed that cable with appropriate pre-stress as a zipper element.

\section{Zipper braced frame}

Engineers found Chevron braced frames difficult to design, since they are not able to distribute unbalanced large forces because of buckling at bracing system. In order to achieve the advantages like the effectiveness of stiffness and resistance to limit the displacement ratio and also ensure the behaviour of the stability of the structure, concentrically zipper-braced frame is shaped. ZBF theory was first proposed in 1988 by Khatib. This system is similar to Chevron system, but only just one additional element, which was a vertical structural member, connected at the top and down to the beams at the mid-span point called strut. This vertical strut named as zipper, and a frame in which zipper braces were added called zipper brace frame.

Zipper columns are attached vertically and lie perpendicular (90 degrees) to floor beams. These columns can transfer the unbalancing force caused by the buckling of the compressive member of the first-story bracing to the bracings in upper stories (Figure $1 \& 2$ ).

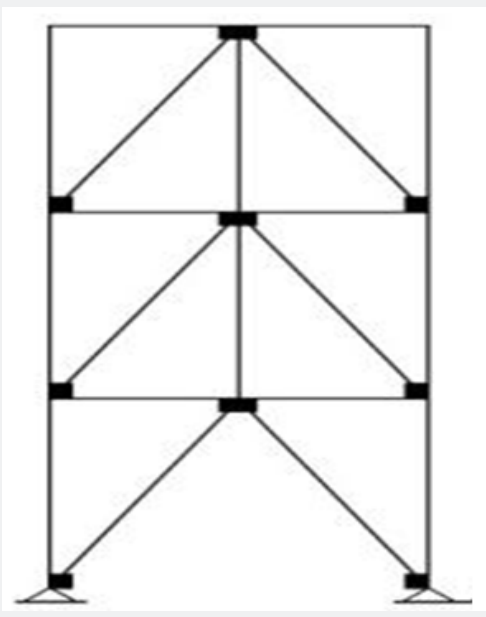

Figure 1: Zipper brace frame (Before buckling).

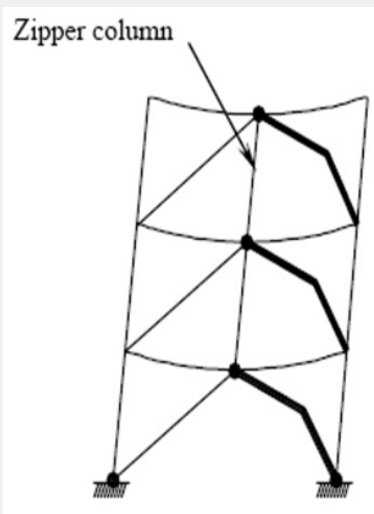

Figure 2: Zipper brace frame (After buckling).
With a proper zipper configuration, it is possible to address the problems and weaknesses of the chevron bracing frame [11].

According to the study of Pourbaba P et al. [5] found that adding vertical Zipper member had good effects on the behaviour of the frames. Thus, as it was seen, while the compressive braced frame members at the first floor was not buckling (at the beginning of lateral loading), internal force in Zipper braced member was zero. Bye using the zipper column in CBF reduction of mid-point deflections of beam in the braced system as well as improvement of ductility.

By using zipper braces seismic performance improve significantly than frame without zipper [12].

\section{Seismic analysis of RC frames by using ETABS 2016}

Kai Hu, Yimeng Yang [13] Time history analysis by SAP200 and ETABS are roughly similar. However, SAP2000 does not have the concept of "storey", which made the post- processing much more complicated.Therefore for regular structure ETABS is recommended.ETABS mainly offers following types of analysis: (a) Linear (b)Nonlinear (c)Pushover Analysis (d)PA Effect Analysis,and for this analysis ETABS gives good result Rinkesh R Bhandarkar [14](Figure 3).

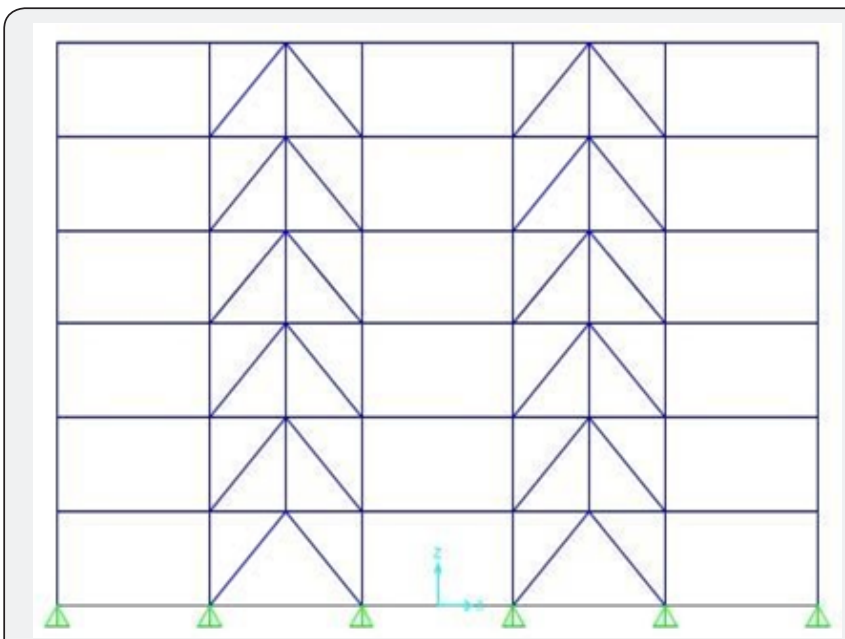

Figure 3: Zipper braced frame.

\section{Seismic Analysis of zipper braced frame}

Time history analysis and pushover analysis is used in past researches.Bill Tremayne[15] time history analysis is more effective than response spectrum method. Time History is realistic method, used for seismic analysis, it provides a better check to the safety of structures analysed and designed by method specified by IS code Patil AS [16], Prakriti chandrakar et al.[2]Time history analysis is a more precise in description of the structure under dynamic load and it can give a more precise approximation of the interior stresses and also the time and position of the cracks emerging in the structure. This method calculates response of structure subjected to earthquake excitation at every instant of time (hence the name Time History). 


\section{Civil Engineering Research Journal}

\section{Seismic performance of zipper braced frame compared with different braced frame}

Adding vertical Zipper member had good effects on the behaviour of the frames. Amount of absorbing energy in Zipper bracing members is more than Chevron [5]. By using the zipper strut it leads to better seismic performance of the structure,by imposing acceleration on the structure and conducting time history analysis, it is observed that the zipperstrut-equipped system shows a stronger tendency to form shear links, leading to greater dissipation capacity in plastic zoneSeyedMehadiZahrai[17].Zipper brace improve lateral strength, ductility, and yielding mechanism than X-bracing Ashwin PC [18]. Seismic performance of different buildings in terms of performance point shows that IVF, VBF and ZBF buildings have higher capacity than other buildings [19].ZBF enhances structural performance against seismic load[20,21]. Bracing element will have very important effect on structural behaviour under earthquake effect [22]. For constant structural weight, structures designed by using zipper braced frame experience up to $50 \%$ less global ductility ratio(damage) compared with code-based structuresVaseghi] [23].

\section{Conclusion}

According to the research the results which were obtained is most promising technique for seismic rehabilitation [1] it is Concluded as in zipper braced frames as number of stories increases, appeared to account for the increased conservatism of the procedure as the number of stories increases [4]. according to the research adding vertical zipper members has good effects on the behaviour of the frames, also internal forces in zipper is zero[5]. The use of suspended zipper concept to rehabilitation and strengthening of structures were economical and practical [7]. In addition by adding zipper columns to chevron bracing systems a more uniform interstorey drift distribution over the building height was observed [9].

\section{References}

1. Kadid A, Yahiaoui D (2011) Seismic Assessment of Braced RC Frames. Procedia Engineering 14: 2899-2905.

2. Prakriti Chandrakar, Bokare PS (2015) A Review-Comparison between Response Spectrum Method and Time History Method for Dynamic Analysis of Multi-storeyed Building. International Journal of Science and Research (IJSR) ISSN (Online): 2319-7064 Index Copernicus Value (2015): 78.96.

3. Naeimi S, Shahamari A, Eimani Kalehsar H (2012) Study of the Behavior of Zipper Braced Frames. wcee.

4. Chuang-Sheng Yang, Roberto T Leon, Reginald Des Roches (2008) Design and behaviour of zipper braced frames. Engineering structures 30(4): 1092-1100.

5. Pourbabaa M, Reza Bagerzadeh Karimia M, Zareib B, Bagheri Azarc B (2013) Behavior of Zipper Braced Frame (ZBF) compared with other Concentrically Braced Frame (CBF). International Journal of Current Engineering and Technology 3(4).
6. Haifeng Yu Tianya Wang, Libin Shi (2013) Research on the seismic performance of zipper frames. Applied Mechanics and Materials 351352: 545-549.

7. Nouri GR, Imani Kalesar H, Ameli Z (2009) The applicability of the zipper struts to Seismic rehabilitation of steel structure. World Academy of Science, pp. 402-405.

8. Rahimi R, Mo R Banan, Ma R Banan (2016) Lateral Cyclic Behavior of Zipper Braced Frames-Considering Connection Details. International Journal of Steel Structures 16(1): 11-21.

9. Lucia Tirca, Liang Chen (2012) The influence of lateral load patterns on the seismic design of zipper braced frames. Engineering Structures 40: 536-555.

10. Razavi M, Sheidaii MR (2012) Seismic performance of cable zipperbraced frames. Journal of Constructional Steel Research 74: 49-57.

11. Mirza Gol tabar Roshan A, Nodeh Farahoni R (2015) An Overview of Pros and Cons of Zipper Braced Frames. Current World Environment 10(1): 106-110.

12. Jeongjae Kim, Chunhee Cho, Kyungkoo Lee, Cheolho Lee (2008) Design of Zipper Column in Inverted V Braced Steel Frames. The $14^{\text {th }}$ World Conference on Earthquake, Beijing, China.

13. Kai Hu, Yimeng Yang, Suifeng Mu, Ge Qu (2012) Study on High-rise Structure with Oblique Columns by ETABS, SAP2000, MIDAS/GEN and SATWE. International Conference on Advances in Computational Modeling and Simulation. Procedia Engineering 31: 474 - 480.

14. Rinkesh R Bhandarkar, Utsav M Ratanpara, Mohammed Qureshi (2017) Seismic Analysis \& Design of Multistory Building Using Etabs. (C) 2017 IJEDR 5(2).

15. Bill Tremayne, Trevor E Kelly (2005) Time history analysis as a method of implementing Performance based design. NZSEE Conference.

16. Patil AS, Kumbhar PD (2013) Time history analysis of multistoried RCC buildings for different seismic intensities. (C) 2013 IJSCER 2(3).

17. Seyed Mehdi Zahrai, Milad Pirdavari, Hamid Momeni Farahani (2013) Evaluation of hysteretic behavior of eccentrically braced frames with zipper-strut upgrade. Journal of Constructional Steel research 83: 10-20.

18. Ashwin Kumar PC, Dipti Ranjan Sahoo, Abhay Kumar (2018) Seismic response of concentrically braced frames with staggered braces in split-x configurations. Journal of Constructional Steel Research 142: 17-30.

19. Yaseer Alashkar, Sohaib Nazar, Mohammad Ahmed (2015) A Comparative Study of Seismic Strengthening of RC building by steel bracing and concrete shear wall. International Journal of Civil and Structural Engineering Research 2(2): 24-34.

20. Ali Paseban, Jalal Jamali (2013) Investigation of the Seismic Behavior of Steel Structures with Zipper Braced Frames. Technical Journal of Engineering and Applied Sciences (C) 2013.

21. Dhanaraj M Patil, Keshav K Single (2015) Seismic Behaviour of Different Bracing Systems in High Rise 2-D Steel Buildings. Structures 3: 282-305.

22. Sangle KK, Bajoria KM, Mmhalungkar V (2012) Seismic analysis of high rise steel frame building with with and without bracings. 15 wcee 2012

23. Vaseghi Amiri J, Esmaeilnia Amiri M, Ganjavi B (2015) Acheivement of minimum seismic damage for zipper braced frames on uniform deformations theory" Journal of rehabilition in civil engineering 3(1): 43-60. 
CC (i) This work is licensed under Creative Commons Attribution 4.0 License DOI: 10.19080/CERJ.2018.05.555675
Your next submission with Juniper Publishers will reach you the below assets

- Quality Editorial service

- Swift Peer Review

- Reprints availability

- E-prints Service

- Manuscript Podcast for convenient understanding

- Global attainment for your research

- Manuscript accessibility in different formats

( Pdf, E-pub, Full Text, Audio)

- Unceasing customer service

Track the below URL for one-step submission https://juniperpublishers.com/online-submission.php 